\title{
Oliko ammattikorkeakoulujen perustaminen yhteiskunnallinen kokeilu?
}

\author{
Osmo Lampinen
}

\begin{abstract}
Ammattikorkeakoulu -uudistus markkinoitiin kokeiluna. Kokeilulaki säädettiin vuonna 1991 ja ensimmäiset kokeilut pääsivät alkamaan syksyllä 1992. Alkuperäisenä ajatuksena oli jatkaa kokeilua vuosituhannen loppuun saakka, minkä jälkeen olisi tehty päätökset vakinaiseen ammattikorkeakoulujärjestelmään siirtymisestä. Paine pysyvään ammattikorkeakoulujärjestelmään siirtymiseksi kasvoi kuitenkin nopeasti ja ensimmäiset ammattikorkeakoulut vakinaistettiin jo vuonna 1996.
\end{abstract} Seuraavassa on tarkoitus kysyä, missä määrin uudistusta voi pitää aitona yhteiskunnallisena kokeiluna.

Ammattikorkeakoulu -uudistuksen suuntaviivat laadittiin opetusministeriössä vuonna 1989. Valmistelu tapahtui virkamiestyönä, eikä siinä käytetty tavanomaista komiteavalmistelun mallia. Julkisen keskustelun avasi ns. visiopaperi, joka esiteltiin julkisesti keväällä 1990 Finlandia-talossa. Ammattikorkeakoulut ja nuorisoasteen yhteistoiminta esiteltiin kannanotossa keinona ratkaista peruskoulun jälkeiseen koulutusjärjestelmään sisältyneet toiminnalliset ongelmat. Ajatus esitettiin väljänä visiona, eikä sen esittäjillä ollut kovin selkeitä käsityksiä uudistuksen mahdollisesta toimeenpanosta.

Ammattikorkeakouluidea sai suopean ja jopa innostuneen vastaanoton eri puolilla Suomea. Ajatusta kuitenkin vierastettiin varsinkin yliopistopiireissä. Suomessa korkeakoulukeskustelua oli käyty melko rajoittuneessa ympäristössä, eikä muiden maiden ammattikorkeakoulumalleja paljonkaan tunnettu. Yliopistopiireissä eli vahvana ajatus että korkeakouluja on Suomessa jo liikaa.

Eduskunta koki tulleensa syrjäytetyksi ammattikorkeakoulu- ja nuorisoasteen uudistusten valmistelussa. Niinpä hallitus oli pakotettu antamaan Eduskunnalle sen vaatiman koulutuspoliittisen selonteon. Tämä selonteko annettiin jo vuonna 1990. Selonteko ja siitä käyty keskustelu keskittyivät suurelta osin ammattikorkeakoulujen ja nuorisoasteen kokeiluihin. Eduskunta ei vastauksessaan suositellut vastustuksen ja epäilyjen takia suoranaisia järjestelmäuudistuksia vaan hallitusta kehotettiin etenemään kokeilujen kautta.

Kokeilu oli hallitukselle ja sen opetusministereille Christoffer Taxellille ja Anna-Liisa Kasuriselle ainoa mahdollisuus edetä koulutusjärjestel- 


\section{KATSA UKSET}

män uudistamisessa. Eduskuntakeskustelu osoitti, ettei pysyvään ammattikorkeakoulujärjestelmään siirtymiselle ollut poliittisia edellytyksiä (Mäenpää 2000,13-15). Kokeilulla haluttiin voittaa aikaa ja suopeutta uudelle ajattelulle. Samalla toivottiin, että kokeilu toisi esille rohkaisevia tuloksia ja selkiyttäisi ammattikorkeakouluja koskevaa linjanvetoa.

Kokeilulaki astui voimaan vuonna 1991. Sen mukaan kokeilu toteutettaisiin syksystä 1991 vuoden 1999 loppuun saakka. Kokeilun tavoitteeksi määriteltiin koulutuksen tason nostaminen, työelämän nopeisiin muutoksiin vastaaminen, ammatillisen koulutuksen vetovoiman lisääminen, ammatillisen koulutusjärjestelmän toimintakyvyn lisääminen, hallinnon hajauttaminen ja koulutuksen alueellisen vaikuttavuuden lisääminen.

Opetusministeriö sai jo ennen kokeilulain toimeenpanoa vastaanottaa suuren määrän kokeiluesityksiä ympäri Suomea. Ensimmäiset kokeiluluvat annettiin hakemusten perusteella 22 väliaikaiselle ammattikorkeakoululle. Nämä koostuivat 85 ammatillisesta oppilaitoksesta, joten useimmat ammattikorkeakoulut olivat monialaisia. Kokeilut sijaitsivat ympäri maata ja edustivat molempia kieliryhmiä. Ensimmäiset kokeilut alkoivat syksyllä 1992.

\section{Kokeiluasetelma}

Suomalaisen ammattikorkeakoulujärjestelmän rakenteellinen perusarkkitehtuuri määriteltiin jo vuonna 1990. Sen mukaan ammattikorkeakoulut tulisivat olemaan usean oppilaitoksen yhtymiä. Uudistus ei pyrkinyt ainoastaan yhdistämään oppilaitoksia vaan tavoitteli niiden tason nostoa. Tavoitteena oli muodostaa yliopistojen rinnalle toinen korkeakoululaitoksen haara. Ammattikorkeakoulut edustaisivat akateemisten yliopistojen vastapainona professionaalisempaa suuntautumista.

Ammattikorkeakoulujen esikuvina olivat Saksan Fachhochschule -ammattikorkeakoulut, Englannin Polytechnic -ammattikorkeakoulut ja Hollannin HBO-instituutit. Esikuvallisuus oli kui-

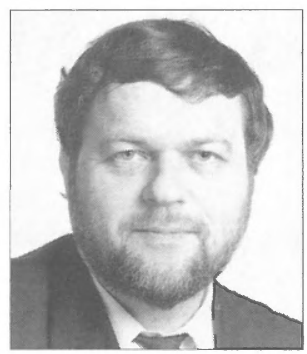

Osmo Lampinen

tenkin vain viitteellistä. Ammattikorkeakoulut rakennettiin puhtaasti kotimaisista rakennuspuista.

Kokeilulaki määritteli kokeilujen tarkoitukseksi selvittää, miten erityisesti eri koulu- ja oppilaitosmuotojen yhteistoiminnalla voidaan edistää peruskoulun jälkeisen koulutuksen tason kohottamista, yhteiskunnan muuttuvien tieto- ja taitovaatimusten tyydyttämistä, joustavien ja yksilöllisten opintokokonaisuuksien muodostumista ja koulutusmahdollisuuksien monipuolistumista sekä koulutusjärjestelmän toimintakyvyn parantamista ja hallinnon kehittämistä.

Kokeilun tavoitteen määrittelyssä pyrittiin yhdistämään yhteen lauseeseen kahden kokeilun, nuorisoasteen yhteistoimintakokeilujen ja ammattikorkeakoulujen tavoitteet. Formulointi kuvasti pikemminkin nuorisoasteen kuin ammattikorkeakoulukokeilujen tavoitteita. Melko pian kävi ilmeiseksi, että ammattikorkeakoulukokeilun menetelmät asettuivat toisin kuin kokeilulain sanamuodot.

Kokeiluyksiköiden valintaa ohjasivat kokeilullisten tavoitteiden ohella yleiset yhteiskunnalliset tekijät. Kokeiluun haluttiin oppilaitoksia eri puolilta Suomea ja molemmista kieliryhmistä. Kokeiluun haluttiin mukaan hyviksi tiedettyjä oppilaitoksia, joskin ulkopuolellekin jätettiin mainetta saaneita oppilaitoksia. Näistä tekijöistä huolimatta kokeiluasetelma sisälsi monia kokeilullisia piirteitä. Tällaisia olivat:

1 Vain osa hakeneista oppilaitoksista hyväksyttiin kokeiluun. 
2 Kokeiluun valittiin eri tyyppisiä oppilaitoksia ja niiden yhdistelmiä. Kokeiluun tuli oppilaitoksia useista oppilaitosmuodoista. Mukana oli yksittäisiä oppilaitoksia, kahden oppilaitoksen yhdistelmiä ja laaja-alaisia yhtymiä. Kokeilut sijoittuivat eri puolille Suomea ja ne edustivat molempia kieliryhmiä.

3 Kokeiluaika oli rajattu. Laki salli uusien opiskelijoiden sisäänoton vuoteen 1995 saakka ja lain voimassaolo tulisi päättymään vuonna 1999.

4 Kokeiluun liittyi laaja seurantajärjestelmä. Tähän kuului valtakunnallisen tietokannan tiedonkeruu, raportointi, erilliset tutkimukset ja arvioinnit. Seurannasta julkaistiin vuosittain valtakunnallinen kokoava raportti.

Kokeilullisuuden näkökulmasta asetelmaan liittyi myös puutteita. Aidon kokeilun toteuttaminen olisi edellyttänyt laajamittaisen vertailevan asetelman käyttöä. Jossain määrin vertailevia tutkimuksia ammattikorkeakouluun valittujen ja muiden opistojen välillä tehtiinkin. Kuitenkin alusta lähtien kävi selväksi, että kokeilu vaikutti myös sen ulkopuolella oleviin oppilaitoksiin. Ne pyrkivät jäljittelemään kokeiluyksiköiden toimintaa halutessaan päätyä itse ammattikorkeakouluiksi. Näin ollen kokeilulla ei ollut aitoa vertailuryhmää.

Vertailuasetelma oli ollut myös muussa suhteessa ongelmallinen. Ammattikorkeakoulukokeilussa toteutettiin rakenteellisia muutoksia, joita taas muissa oppilaitoksissa ei tehty. Joidenkin alojen opinnot pidentyivät, ammattikorkeakoulututkinnot määriteltiin korkeakoulututkinnoiksi ja ammattikorkeakoulut saivat toimintansa tueksi ylimääräistä rahoitusta. Näistä tekijöistä johtuen ammattikorkeakoulut olivat edullisemmassa asemassa kuin ulkopuoliset oppilaitokset ja niistä tuli pyrkineiden suhteen muita suositumpia.

Yhteiskunnallisen kokeilun yleisenä ongelmana on, että ulkoisia tekijöitä on miltei mahdoton kontrolloida. Melko pian kokeilun alkamisen jälkeen Suomen talous ajautui vaikeaan lamaan. Lama pakotti supistamaan kokeiluoppilaitosten voimavaroja, millä oli ilmeisiä vaikutuksia oppilaitosten toimintaan. Valinnaisuutta jouduttiin supistamaan samoin kuin kontaktiopetuksen määrää, mikä tosin saattoi osaltaan tukea kokeilun alkuperäisiä tavoitteita. Kokeiluaikana vuonna 1994 Suomi liittyi EU:hun, mikä toi oppilaitosten käyttöön entistä laajemmat yhteistyömahdollisuudet ulkomaisten oppilaitosten kanssa.

Kokeilun seuranta keskittyi yksittäisten ammattikorkeakoulujen kehittymisen seurantaan. Alkuperäisenä ajatuksena oli tutkia kokeilun avulla myös koko ammattikorkeakoulujärjestelmän toimivuutta. Tähän kokeilujakso oli alun perinkin liian lyhyt. Järjestelmän toimivuus olisi edellyttänyt, että käytettävissä olisi ollut tiedot usean opiskelijaikäluokan sijoittumisesta koulutukseen tai työelämään opintojen jälkeen. Vasta kokeilujen jälkeiset tulokset ovat osoittaneet, että uusi dualistinen korkeakoulujärjestelmä ohjasi opiskelijavirtoja jokseenkin odotetulla tavalla.

\section{Kokeilusta vakinaistumiseen}

Ammattikorkeakoulukokeilulla oli julkilausutun tavoitteen ohella piilotavoitteena voittaa aikaa kokeilun hyväksymiselle. Tämän piilofunktion merkitys kasvoi, kun hallitus vaihtui vuonna 1991. Opetusministeriksi nousi Ruotsalaisen kansanpuolueen Cristoffer Taxellin ja hänen seuraajansa Ole Norrbackin jälkeen ammattikorkeakouluihin ja nuorisoasteen kokeiluihin kriittisesti suhtautunut Kokoomuksen Riitta Uosukainen. Ministerin vaihdos vaikutti kahdella tavalla. Uosukainen oli pidättyväinen uusien kokeilujen käynnistämisessä, mikä toi kokeiluasetelmalle pysyvyyttä. Kokeiluasetelmaa laajennettiin Uosukaisen kaudella vain kahdella pääkaupunkiseudun ja yhdellä maakunnallisella kokeiluyksiköllä. Muutoin laajentamista jatkettiin vasta seuraavan ministerin Olli- Pekka Heinosen kaudella.

Ministerin kriittinen asenne korosti kokeilutulosten merkitystä. Siitä tuli keino, jolla virkamiehistö ja uudistuksen ajajat perustelivat ammattikorkeakoulujen merkittävyyttä. Uosukainen päätyi ministerikautensa viimeisinä viikkoina kannattamaan ammattikorkeakoulujen korvaamis- 
ta Itävallan mallin mukaisella tutkinnonanto-oikeusjärjestelmällä, mikä olisi merkinnyt kokeilujen lopettamista. Tästä tavoitteesta luovuttiin kuitenkin hänen seuraajansa astuttua ministeriksi.

Olli-Pekka Heinonen jakoi edeltäjänsä epäluuloisuuden ammattikorkeakouluja kohtaan. Hänestä tuli kuitenkin ministeri, joka käytännössä ratkaisi ammattikorkeakouluverkon rakenteen alkuperäisen Taxellin vision suuntaisesti.

Päinvastoin kuin ministeriön poliittinen päättäjä, kokeiluyksiköt olivat hyvin motivoituneita. Alkuvaiheessa osa opettajista asennoitui kokeiluun kriittisesti ja piti entiseen palaamista toivottavana. Myös opiskelijat kritisoivat kokeilua erityisesti sen synnyttämän epävarmuuden takia (Kurtakko, Mutka 1995). Enemmistö opettajista ja opiskelijoista suhtautui kokeiluun myönteisesti ja oppilaitokset pyrkivät saavuttamaan kokeilun tavoitteiden mukaisia tuloksia. Myöhemmin kriittisten opettajienkin mielipiteet muuttuivat.

Ammattikorkeakoulu -uudistusta markkinoitaessa monet kriitikot leimasivat sen kyltinvaihdoksi (Lampinen, Savola 1995,26-80). Ensimmäiset myönteiset kokeilutulokset vaiensivat kuitenkin tämän kritiikin. Kokeilutulokset osoittivat, että kokeilu tuotti muutoksia oppilaitosten toiminnassa. Erityisesti kansainvälistyminen eteni nopeasti. Myös opetusmenetelmät muuttuivat siten, että yhä suurempi osa opetuksesta tapahtui luokkahuoneen ulkopuolella. Useat arvioitsijat antoivat myönteisen kuvan kokeilun etenemisestä. Tärkein ammattikorkeakoulujen legitimiteettiä lisännyt kannanotto oli OECD-eksperttien arviointi vuodelta 1995.

OECD-arvioijien yksi keskeisimpiä suosituksia koski erityisen tukiohjelman laatimista ammattikorkeakoulujen kehittymisen tukemiseen. Arviointiraportin seurauksena opetusministeriö lisäsikin jo aiemmin käynnistynyttä kokeiluyksiköiden tukemista. Erillisellä rahoituksella tuettiin mm. opettajien kouluttautumista, kirjastoja informaatiopalvelujen kehittämistä, ura- ja rekrytointipalvelujen luomista ja kansainvälistymistä.
Yleinen käsitys kokeilukentällä oli, että kokeilu on vain välivaihe siirryttäessä vakinaiseen ammattikorkeakoulujärjestelmään. Niinpä monet oppilaitokset ja niiden tukena läänit ja maakuntahallitukset alkoivat painostaa hallitusta pysyvän järjestelmän aikaansaamiseksi. Yleisesti koettiin myös kohtuuttomaksi, että puolet opistoasteen oppilaitoksista oli kokeilussa ja puolet sen ulkopuolella.

Aika ja kokeilutulokset olivat tehneet tehtävänsä ja hallitus saattoi antaa pysyvää ammattikorkeakoulujärjestelmää koskevan lakiesityksen Eduskunnalle marraskuussa 1994. Pysyvä lainsäädäntö ei hengeltään ja yleistavoitteiltaan eronnut kokeilulaista. Se kuvasteli kokeilukauden aikana kypsyneitä ajatuksia. Ammattikorkeakouluista pyrittiin tekemään instituutioina vahvoja ja korostettiin niiden monialaisuutta sekä maakunnallista luonnetta. Ensimmäiset pysyvät ammattikorkeakoululuvat myönnettiin lain perusteella vuonna 1996.

Vanhaa kokeilulakia ei peruttu. Kokeilusta tuli entistä selvemmin siirtymävaihe oppilaitosten siirtyessä opistoasteelta pysyväksi ammattikorkeakouluksi. Tavoitteena oli, että kaikki ammattikorkeakoulut ja niiden yksiköt kävisivät läpi kokeiluvaiheen, jonka tulosten perusteella päätettäisiin vakinaistamisesta. Tästä periaatteesta ei kuitenkaan myöhemmin pidetty kiinni kaikissa ratkaisuissa, vaan hallitus myönsi vakinaistamisluvan myös joillekin kokeilua läpikäymättömille oppilaitoksille.

Lain mukaan pysyvät toimiluvat myönnetään koulutuksen laadun ja kokeiluvaiheessa savutettujen tulosten perusteella. Lainsäädäntö mainitsi 12 kriteeriä toimilupa-anomusten arviointiin. Kriteerit myötäilivät ammattikorkeakoulu -uudistuksen alkuperäisiä tavoitteita, mutta olivat täsmällisemmin ilmaistuja. Niiden muotoiluun vaikutti pyrkimys muodostaa organisaatioltaan ja toiminnaltaan virtaviivaisia ja tavoitehakuisia oppilaitoksia.

Ensimmäiset toimilupa-arvioinnit suoritti tilapäinen työryhmä. Myöhemmin arvioinnit siirtyivät korkeakoulujen arviointineuvostolle. 
Oli ilmeistä, että pysyvän lainsäädännön säätämisen jälkeen oppilaitosten kiinnostus siirtyi opetusministeriön ja ympäristön odotuksista arviointiryhmien ja arviointineuvoston toimintapolitiikkaan. Tärkeäksi tuli pyrkiä vastaamaan arviointia suorittavien toimielinten asettamiin kehittymiskriteereihin, ei niinkään kokeilun alkuperäisten tavoitteiden saavuttamiseen.

Hallitus myönsi elokuussa 1996 yhdeksälle ammattikorkeakoululle toimiluvan. Tämän jälkeen toimilupia on myönnetty joka vuosi. Osa myönnetyistä luvista on ehdollisia, joten ne edellyttävät oppilaitokselta kehittämistoimenpiteitä. Vuonna 2000 ammattikorkeakoulujärjestelmä koostuu 29 pysyvästä ammattikorkeakoulusta, jotka sijaitsevat eri puolilla maata. Useimmat ammattikorkeakoulut ovat monialaisia.

\section{Kokeilun paradoksit}

Ammattikorkeakoulukokeilu sisälsi kaksi paradoksia. Näistä ensimmäinen oli, että kokeilun piilotavoitteista tuli ennen pitkää varsinainen tavoite. Piilotavoitteena oli voittaa aikaa ja suopeutta pysyvälle ammattikorkeakouluratkaisulle. Tässä piilotavoitteessa onnistuttiin hyvin. Ammattikorkeakoulut tulivat hyväksytyiksi ennen kuin kokeilun lopulliset tulokset olivat käytettävissä. Sen jälkeen, kun pysyvää järjestelmää koskeva lainsäädäntö oli säädetty, kokeilu muuttui siirtymismenetelmäksi, jolla pysyvä ammattikorkeakouluverkosto synnytettiin.

Toinen kokeilun paradoksi koski kokeilutoiminnan tavoitteen määrittelyä. Kokeilun menetelmä määriteltiin virheellisesti ja itse menetelmä, oppilaitosten yhteistoiminta, joutui kehittämistoimenpiteiden kohteeeksi. Kokeilun todellisiksi menetelmiksi muodostui oppilaitosten arvostuksen lisääminen ja niiden kehittämistoiminnan tukeminen, millä pyrittiin saavuttamaan kokeilulainsäädännön tavoitteet.

Kokeilulaki määritteli oppilaitosten yhteistoiminnan kokeilujen pääasialliseksi menetelmäksi. Alun perin ammattikorkeakoulukokeiluun otettiin mukaan myös yksittäisistä oppilaitoksista koostuvia kombinaatioita. Ajateltiin, että niiden toimivuutta voitaisiin vertailla. Mutta ennen kuin mitään vertailuja voitiin tehdä, tuulet muuttuivat. Vallalle pääsi käsitys, että ammattikorkeakoulujen tulee olla suuria moninaisia yksiköitä, jotka palvelevat maan eri alueita ja kieliryhmiä. Tältä pohjalta vakinaistuminen lähti käyntiin.

Mahdollisia kokeilutuloksia enemmän ammattikorkeakouluverkoston kehitykseen vaikuttivat yleisessä yhteiskunnallisessa ilmastossa tapahtuneet muutokset. Oppilaitosverkkoa haluttiin laman oloissa rankasti rationalisoida. Maakunnallisuus nosti päätään. Järjestelmän ohjattavuuteen alettiin kiinnittää enemmän huomiota. Myös ulkomaiset kokemukset viestittivät suurten, monialaisten ammattikorkeakoulujen vetovoimaa.

Tämä kehitys alkoi vaikuttaa ennen kuin kokeilusta oli tullut yhtäkään tulosta. Itse asiassa vieläkin on epäselvää se, minkälaiset oppilaitoskokonaisuudet olisivat olleet toimivimpia (Turkulainen 1998).

Kokeilulaki nimesi kokeilun pääasiallisen menetelmän epätarkasti. Lakiin olisi pitänyt kirjata oppilaitosten yhteistoiminnan sijaan kokeilun menetelmäksi oppilaitosten aseman kohottaminen koulutushierarkiassa ja panostaminen oppilaitosten sisäiseen uudistustyöhön.

Jos kokeilun perusongelmana olisi kysytty, voitiinko oppilaitosten arvostusta kohottamalla ja niiden kehittämistoimintaa tukemalla edistää koulutuksen laadullista kehittämistä, onnistui ammattikorkeakoulukokeilu kokeiluajan kuluessa tuottamaan myönteisen vastauksen.

Seurantatiedot osoittavat kiistattomasti, että kokeiltavissa ammattikorkeakouluissa tapahtui huomattavaa laadullista kehittymistä mm. opettajien koulutustason nostamisen, opetusmenetelmien kehittämisen, kansainvälisyyden, tutkimus- ja kehitystoiminnan ja työelämäsuhteiden alueilla.

Ammattikorkeakoulun tuoma arvostuksen nousu ja opetusministeriön tukitoimenpiteet motivoivat oppilaitoksia kehittämään ja uudistamaan vahvasti toimintaansa. Ammattikorkeakoulujen toimintatapa- ja kulttuuri muuttui korkeakou- 
lumaisemmaksi. Uuden tiedon välittämisen, luokkaopetuksen, luentojen ja kertaamisen osuus vähentyi merkittävästi opiskelijan omatoimisen opiskelun tieltä. Ammattikorkeakoulut suunnistivat myös tutkimus ja kehitystoiminnan kentälle ja olivat aktiivisia työelämäsuhteiden kehittämisessä (Numminen, Lampinen 1996).

Raijaliisa Laakkosen tekemässä Keski-Pohjanmaan ammattikorkeakoulun seurantatutkimuksessa (Laakkonen 1999) kaikki haastatellut opettajat arvioivat, että uudistuksella on edistetty alkuperäisiä tavoitteita. Oulun seudun ammattikorkeakoulussa $96 \%$ opettajista katsoi, että ammattikorkeakoulun opintokokonaisuuksien sisällöt ovat vaativammat kuin keskiasteen koulutuksessa.

Ammattikorkeakoulukokeilu loi tunteen isosta muutos- ja kehittämisprojektista. Näin ajatteli 2/ 3 opettajista Pohjois-Savon ammattikorkeakoulussa vuonna 1999. Kriittiseksi kysymykseksi jää ettei kokeiluvaihe monien vastaajien mielestä kyennyt selkiyttämään ammattikorkeakoulujen profiilia. Pohjois-Savon asetelmassa vastaajista 28 \%:n mielestä ammattikorkeakoulujen profiili ja asema on selkiytynyt melko vähän ja 17, 5 \%:n mielestä ei lainkaan (Laurinkari 2000).

\section{Kokeilun merkitys ja asema}

Yhteiskunnallisten kokeilujen mahdollisuuksista on käyty runsaasti keskusteluja. Vielä 1960-ja 1970-luvulla monet tutkijat unelmoivat mahdollisuudesta perustaa yhteiskunnallinen kehitys laajaan kokeilutoimintaan (Campell 1969). Tämän ajattelun pohjalla oli positivistinen ajatustapa. Uskottiin että yhteiskuntatieteellinen tutkimus voi tuottaa luonnontieteille tyypillisiä eksakteja ja kiistattomia tuloksia, jotka ovat siirrettävissä käytäntöön.

Myöhemmin on oltu kriittisempiä mahdollisuuteen toteuttaa yhteiskunnallisessa elämässä kontrolloituja kokeita, joissa käytettäisiin luonnontieteiden tapaan kontrolli- ja vertailuryhmiä. Vertailujen mahdollisuus on rajallinen, koska yksittäisten ihmisten ja sosiaalisten ryhmien toiminta on tarkoitushakuista ja muuttuu ulkois- ten odotusten mukana. Metodologisten ongelmien ohella esille ovat nousseet myös eettiset ongelmat. Kontrolloitu asetelma sallii tutkijalle täyden vapauden, mutta vaatii tutkittavilta passivisuutta ja toiminnan determinismiä (Rajavaara $1999,28-36)$.

Tutkimuksen hyväksikäyttöä koskeva tutkimus on osoittanut, etteivät tutkimustulokset siirry käytäntöön suoraviivaisesti. Selvimmin yhteiskuntatieteellisellä tutkimuksella voi olla asenteita ja ajattelutapoja muuttava vaikutus. Sen sijaan itse päätösten muotoiluun tutkimus vaikuttaa harvemmin. On myös havaittu, että päättäjät käyttävät tietoa puutteellisesti ja vain siinä määrin kuin se tukee muita tavoitteita ja päämääriä (Lampinen 1992).

Ammattikorkeakoulukokeilu osoittaa sekä kokeilullisen menetelmän että sen hyväksikäytön rajoituksia. Kokeiluasetelmaa oli mahdoton rakentaa kontrolloidun tilastoasetelman pohjalle. Kokeilun tavoitteiden muotoilu oli poliittinen prosessi, jossa muut kuin tieteelliset tekijät olivat painavampia. Tutkijat ottivat vain vähän osaa tutkimusasetelman laatimiseen.

Kokeilun asetelma muuttui kokeilun aikana ja menetelmänä määritelty tekijä muuttui itse kehittämisen kohteeksi. Eri oppilaitoskombinaatioiden toimivuudesta saatiin vähän tietoja. $\mathrm{Ne}$ eivät olisi vaikuttaneet päätöksiin, koska yleinen yhteiskunnallisen ilmaston muutos sääteli valitun toimintatavan.

Kokeilutulosten hyväksikäyttö noudatti muutoinkin tutkimuksissa havaittua kaavaa. Tutkimustulokset olivat merkittäviä siinä määrin kuin ne tukivat muita argumentteja. Ne tukivat uudistajien pyrkimyksiä ja vaimensivat kritiikkiä. Kriitikot eivät voineet käyttää tuloksia aseenaan. On kuitenkin kysyttävä, missä määrin kokeiluaikana tapahtuneeseen mielialojen muutokseen olisi päädytty ilman kokeilutuloksiakin.

Ammattikorkeakoulu -uudistus oli luonteeltaan yhteiskunnallista kehittämistyötä., johon liittyi jossain määrin kokeilullisia elementtejä. Sitä ei voida pitää tieteellisessä merkityksessä aitona 
kokeiluna, koska kokeiluasetelmaan liittyi vakavia puutteita ja rajoituksia. Ilmeistä kuitenkin on, että kokeilu-termin käyttö retorisena keinona edesauttoi kehittämistyön käyntiinlähtöä ja toi sen etenemiselle uskottavuutta.

\section{Lähteet}

CAMPELL, Donald. T. (1969) Reforms as experiments. American Psychologist nro 4, 409-429

JOKELA, Pentti (1998) Ammattikorkeakouluopetuksen syntyvaiheet Keski-Pohjanmaalla. Keski-Pohjanmaan ammattikorkeakoulu, Kokkola

KURTAKKO, Kyösti ja Anne Mutka (1995) Paluuta entiseen ei ole. Seinäjoen ammattikorkeakoulun julkaisuja, Seinäjoki

LAAKKONEN, Raijaliisa (1999) Ammattikorkeakoulureformi ja opettajan työnkuvan muutos. Opettajien käsityksiä ammattikorkeakoulukokeilun toteuttamisesta Keski-Pohjanmaalla 1993-1997. Acta Wasaensia, Vaasa

LAMPINEN, Osmo (1992) The utilization of social science research in public policy. VAPK-kustannus, Helsinki

LAMPINEN, Osmo ja Marita Savola (1995) Ammattikorkeakoulujen syntyvaiheet Suomessa. Teokses- sa Lampinen, O. (toim.): Ammattikorkeakoulut Vaihtoehto yliopistolle, Gaudeamus

LAURINKARI, Juhani (toim. 2000) Pohjois-Savon väliaikainen ammattikorkeakoulu. Kokeilusta vakinaiseksi ammattikorkeakouluksi 1992-1998, Pohjois-Savon liitto, Kuopio

MÄENPÄÄ, Heikki (2000) Suomalaisen ammattikorkeakoulujärjestelmän synty, kasvu ja kehitys. Kirjassa Hämeen härkätietä tiedon valtateille. Hämeen ammattikorkeakoulun synty ja kehitys. Hämeen ammattikorkeakoulu. Hämeenlinna

NUMMINEN, Ulla, Lampinen, Osmo ja Mykkänen Tarmo (1996) Nuorisoasteen koulutuskokeilut ja ammattikorkeakoulukokeilut. Raportti 6. Lukuvuosi 1994-1995. Opetusministeriö. Koulutus- ja tiedepolitiikan linja

OECD (1995) Reviews of national policies for education: Finland Higher Education, Paris

ORELMA, Ari ja Marjo-Riitta Järvinen (2000) EteläKarjalan ammattikorkeakoulun ensimmäinen vuosikymmen. Etelä-Karjalan ammattikorkeakoulun julkaisuja. Lappeenranta

RAJAVAARA, Marketta (1999) Arviointitutkimuksen hyödynnettävyys. Kirjassa Risto Eräsaari (toim.) Arviointi ja asiantuntijuus, Tampere

TURKULAINEN, Markku (1998) Monialaisuus ammattikorkeakouluissa. Loppuraportti. Joensuun yliopisto. Joensuu

\section{VERKOT JA TEKNOLOGIA aikuisopiskelun tukeno}

MILLAINEN on verkko aikuisen oppijan oppimisympäristönä? Aikuiskasvatuksen 42. vuosikirjassa käsitellään teknologian ja verkkojen merkitystä aikuiskoulutuksessa. Kirjassa nostetaan tarkastelun kohteeksi lupaavia mahdollisuuksia, mutta myös niitä rajoituksia ja ongelmia, joita teknoplogian hyödyntämiseen liittyy opettamisen ja oppimisen kannalta. Kirjan yhtenä tavoitteena on ohjata virtuaaliopetuksesta käytävää keskustelua pedagogiikkaan, ennen muuta verkkopedagogiikan analyysiin.

Kirjan 12 artikkelia perustuvat uusimpaan tutkimukseen ja viime vuosien käytännön kokemuksiin.

KIRJOITTAJAT: Kai Hakkarainen, Liisa Ilomäki, Kari Kiviniemi, Jukka Koivisto, Leena Laurinen, Jyri Manninen, Ulla Martikainen-Florath, Miika Marttunen, Frans Mäyrä, Anne Nevgi, Juha Pohjonen, Jari Sarja, Juha Suoranta, Kirsi Tirri ja Tuukka Tomperi. Toimittajat: Pekka Sallila ja Pekka Kalli

JULKAISIJAT: Kansanvalistusseura ja Aikuiskasvatuksen Tutkimusseura 2001. KUSTANTAJA: BTJ Kirjastopalvelu OY

TILAUKSET: Kansanvalistusseura, info@kvs.fi tai 09-54918800 HINTA: $185 \mathrm{mk}+$ toimituskulut (414 sivua) 